\title{
Characteristics of reduced fat mayonnaise using pumpkin flour (Cucurbita moschata) as fat replacer
}

\author{
Hemas Azizila Nidhal ${ }^{1}$, Herly Evanuarini ${ }^{1 *}$, and Imam Thohari ${ }^{1}$ \\ ${ }^{1}$ Faculty of Animal Science, Universitas Brawijaya Malang, 65145, Indonesia
}

\begin{abstract}
Reduced fat mayonnaise has the disadvantage of destabilization of emulsion. Emulsion destabilization that occurs is the separation of oil and water. Pumpkin flour is used to increase the viscosity and stability of the emulsion. The objective of this study was to determine the best percentage of the use of pumpkin flour in reduced fat mayonnaise based on $\mathrm{pH}$, emulsion stability, moisture content, and sensory evaluation. The material used in this research was mayonnaise made from egg yolk, canola flower oil, vinegar, pumpkin flour as a fat replacer carbohidrates based, and other optional ingredients. The method used was an experimental laboratory with a completely randomized design with 4 treatments and 4 replications. The treatments consisted of without the use of pumpkin as a control, the use of pumpkin flour $2 \%, 4 \%$, and $6 \%$ of the total oil used. The variables measured were $\mathrm{pH}$, emulsion stability, moisture content, and sensory evaluation. The results showed that the use of pumpkin flour on mayonnaise gave highly significant effect on $\mathrm{pH}$, stability emulsion, moisture content and increased panelists preferences. The conclusion of the study that using $6 \%$ pumpkin flour produced the best reduced-fat mayonnaise.
\end{abstract}

\section{Introduction}

Mayonnaise is one of the processed products which is an oil in water $(\mathrm{o} / \mathrm{w})$ emulsion in semi-solid form. Mayonnaise has a thick and creamy texture. The color of mayonnaise is generally white to yellowish-white with a distinctive sour aroma. The type of mayonnaise generally consists of a traditionally mayonnaise of at least $66 \%$ oil, reduced-fat mayonnaise of at least $50 \%$ oil, and low-fat mayonnaise of at least $25 \%$ oil [1]. Vegetable oil is used full-fat mayonnaise production in high quantities, causing the consumption of mayonnaise in the community to be limited. Foods that contain high fat are harmful to health of consumers. Reduced-fat mayonnaise is prepared by reducing the use of oil in full-fat mayonnaise. Reducing the volume of vegetable oil in reduced-fat mayonnaise can cause destabilization emulsion between the oil phase and the water phase. The emulsion system in mayonnaise is formed in the presence of a mixture of two or more food ingredients, namely emulsifiers and stabilizers. The addition of a stabilizer in reduced-fat mayonnaise will form

* Corresponding author: herlyfptub@ub.ac.id 
a stable emulsion system. Stabilizers have the main function of stabilizing emulsions, binding water, improving texture, and thickening for food [2]. One source of natural stabilizers that is abundantly available in Indonesia is pumpkin which contains pectin. Pumpkin contains carotene, vitamins, minerals, fiber, and pectin which are good for health [3]. Pectin contained in pumpkin is hydrocolloid or water binding. Hydrocolloids play an important role in the food industry, one of which is as a stabilizer [4]. The content of pectin in food shows antioxidant activity, besides that it also contains vitamin $\mathrm{C}$, carotenoids, and phenolic compounds. Pumpkin contains $1.27 \%$ pectin with a weight of $2.4 \mathrm{~kg}$ [5]. Pumpkin contains $92.24 \%$ water content, $0.15 \%$ fat, $0.98 \%$ protein, $0.76 \%$ ash, $0.56 \%$ crude fiber, and $5.31 \%$ carbohydrates [6]. Some natural stabilizers that have been used previously are the use of banana peel waste in the form of flour which is added to reduced-fat mayonnaise [17]. The addition of $6 \%$ watermelon rind flour as a natural stabilizer was able to increase the physicochemical quality from reduced-fat mayonnaise [18]. Based on the content and properties possessed by pumpkin, it can be added to reduced-fat mayonnaise in the form of flour. The use of pumpkin flour as a stabilizer can be used as a fat replacer from carbohydrates and has hydrocolloid properties. The purpose of this study was to determine the appropriate percentage of addition of pumpkin flour to reduced-fat mayonnaise on $\mathrm{pH}$ values, moisture content, emulsion stability, and sensory evaluation.

\section{Materials and methods}

\subsection{Materials}

The ingredients for making mayonnaise are canola flower oil (70\% for control and $50 \%$ for reduced-fat mayonnaise), $5 \%$ vinegar, $20 \%$ egg yolk, $3 \%$ sugar, $1 \%$ salt, $0.5 \%$ white pepper powder, and $0.5 \%$ mustard. Addition of pumpkin flour according to the treatment, namely $2 \%, 4 \%$, and $6 \%$. The research materials for variable testing were distilled water, $\mathrm{pH} 4$ buffer, and $\mathrm{pH} 7$ buffer. The tools used for variable testing were analytical balance, $\mathrm{pH}$ meter, beaker glass, petri dish, oven, desiccator, test tube, centrifuge and questionnaire sheet. While the tools used to make mayonnaise are mixers, spatulas, and analytical scales.

\subsection{Methods}

The method used in this study is a laboratory experiment method with a completely randomized design with four treatments and four replications presented in Table 1.

Table 1. Experimental design and research treatment

\begin{tabular}{|l|l|}
\hline Treatments & \multicolumn{1}{|c|}{ Descriptions } \\
\hline Control & FFM control with $70 \%$ oil \\
\hline T1 & RFM with $50 \%$ oil and $2 \%$ pumpkin flour \\
\hline T2 & RFM with $50 \%$ oil and $4 \%$ pumpkin flour \\
\hline T3 & RFM with $50 \%$ oil and $6 \%$ pumpkin flour \\
\hline
\end{tabular}




\subsection{Pumpkin flour preparation}

The pumpkin used for the study was purchased from the traditional market in Pudjon District, Batu City, East Java Province. The pumpkin is first peeled and seeds removed. Pumpkin was cut into $3 \times 3 \mathrm{~cm}$ sizes and put in an oven at $60^{\circ} \mathrm{C}$ for 48 hours until the weight was constant. The dried pumpkin was mashed using a dry mill, sieved using an 0,177 millimeters sieve, and the pumpkin flour was ready to use.

\subsection{Mayonnaise preparation}

Mayonnaise production begins by mixing the ingredients into a plastic basin. The ingredients mixed are salt, sugar, mustard, and powdered white pepper using a mixer at $1500 \mathrm{rpm}$ for 1 minute. Added egg yolks into a bowl, then added oil interspersed with vinegar. The ingredients are mixed to form an emulsion. Add the apple peel flour and pumpkin to the mayonnaise and mix for 10 seconds.

\subsection{Data analysis}

Data were analyzed statistically using analysis of variance (ANOVA). If there are results that show a difference in influence between treatments, it is followed by Duncan's Multiple Range Test.

\section{Results and Discussion}

\section{1. $\mathrm{pH}$ value}

The results of ANOVA show that the addition of pumpkin flour in different rations had a highly significant effect on the $\mathrm{pH}$ value of mayonnaise $(P<0.01)$. Table 2 shows the average $\mathrm{pH}$ of mayonnaise with pumpkin flour added.

Table 2. The average $\mathrm{pH}$ value of reduced-fat mayonnaise

\begin{tabular}{|l|c|}
\hline Treatments & pH value \\
\hline Control & $4.91 \pm 0.08^{\mathrm{b}}$ \\
\hline $\mathrm{T} 1$ & $4.52 \pm 0.09^{\mathrm{a}}$ \\
\hline $\mathrm{T} 2$ & $4.66 \pm 0.07^{\mathrm{a}}$ \\
\hline T3 & $4.97 \pm 0.03^{\mathrm{b}}$ \\
\hline
\end{tabular}

Note: ${ }^{\mathrm{a}, \mathrm{b}}$ Several superscripts in the same column showed a very significant difference $(P<0.01)$ from the $\mathrm{pH}$ value of mayonnaise.

The $\mathrm{pH}$ of mayonnaise plays an important role in the structure and stability of the emulsion formed. The $\mathrm{pH}$ of mayonnaise is affected by the use of egg yolk, vegetable oil, mustard, and vinegar in the mayonnaise-making process. The $\mathrm{pH}$ of mayonnaise is affected by the isoelectric point $\mathrm{pH}$ of the yolk protein, which plays an important role in the structure and stability of the mayonnaise emulsion [7]. Increasing the percentage of 
addition of pumpkin flour will increase the $\mathrm{pH}$ value of mayonnaise. This is because the $\mathrm{pH}$ of pumpkin flour is 6.6 .

\subsection{Moisture content}

The results of ANOVA show that the addition of pumpkin flour in different rations had a highly significant effect on the moisture content of mayonnaise $(P<0.01)$. Table 3 shows the average moisture content of mayonnaise with pumpkin flour added.

Table 3. The average moisture content of reduced-fat mayonnaise

\begin{tabular}{|l|c|}
\hline Treatments & Moisture content (\%) \\
\hline Control & $21.34 \pm 0.09^{\mathrm{d}}$ \\
\hline T1 & $20.60 \pm 0.07^{\mathrm{c}}$ \\
\hline T2 & $19.43 \pm 0.08^{\mathrm{b}}$ \\
\hline T3 & $18.32 \pm 0.05^{\mathrm{a}}$ \\
\hline
\end{tabular}

Notes: ${ }^{\mathrm{a}, \mathrm{b}, \mathrm{c}, \mathrm{d}}$ Several superscripts in the same column showed a very significant difference $(P<0.01)$ from the moisture content of mayonnaise.

Moisture plays an important role in the end result of the emulsion product, which affects the balance of protein content and fat content. The moisture content of reduced-fat mayonnaise comes from the ingredients used in its production, namely vinegar as an acidulant. Adding water and vinegar to reduce the oil concentration may increase the moisture content of the mayonnaise. [8]. The addition of pumpkin flour to mayonnaise causes a decrease in moisture content. Pumpkin contains pectin which has high anhydrogalacturonic acid and methoxyl [9]. Pectin in pumpkin flour has anhydrogalacturonic acid which is higher than the ash content. The heating treatment of pumpkin flour for too long causes the hydrolysis of pectin into galacturonic acid. Galacturonic acid plays an important role in the formation of the structure and texture of the pectin gel. The texture of reduced-fat mayonnaise with the use of pumpkin flour has a good consistency. Pectin is a hydrocolloid, which can bind water when added to food products. Another important role of hydrocolloids is that they can be used as food stabilizers. Another property of pectin is that it can form a gel at very low concentrations [10]. The content of carotenoids and vitamin $\mathrm{C}$ in pumpkin is higher than the content of sugar, starch, and total protein [11].

\subsection{Emulsion stability}

The results of ANOVA show that the addition of pumpkin flour in different rations had a highly significant effect on the stability of mayonnaise emulsion $(P<0.01)$. Table 4 shows the average stability emulsion of mayonnaise with pumpkin flour added.

The stability of the mayonnaise emulsion is influenced by the use of egg yolk, vegetable oil, acidifier, and the addition of stabilizer. Adding pumpkin flour increases the stability of the mayonnaise emulsion. Pumpkin flour has hydrophilic colloidal properties can be used as a stabilizer in reduced-fat mayonnaise. Destabilization of emulsion in mayonnaise is 
characterized by the separation of oil and water. The use of pumpkin flour will stabilize the oil phase and the water phase. Reduced-fat products are made by decreasing the dispersed phase and increasing the dispersing phase. The oil phase serves to achieve emulsion stability and prevent destabilization, but low-fat products can use a stabilizer.

Table 4. Average emulsion stability of reduced-fat mayonnaise

\begin{tabular}{|l|c|}
\hline Treatments & Emulsion stability (\%) \\
\hline Control & $89.29 \pm 0.06^{\mathrm{c}}$ \\
\hline T1 & $86.60 \pm 0.05^{\mathrm{a}}$ \\
\hline T2 & $88.53 \pm 0.05^{\mathrm{b}}$ \\
\hline T3 & $90.70 \pm 0.05^{\mathrm{d}}$ \\
\hline
\end{tabular}

Notes: ${ }^{\text {a,b,c,d }}$ Several superscripts in the same column showed a very significant difference $(P<0.01)$ from the stability emulsion of mayonnaise.

\subsection{Sensory evaluation}

Table 5 shows the results of the comprehensive evaluation of aroma, texture, tastem color, and mayonnaise overall acceptance.

Table 5. Average mayonnaise sensation assessment

\begin{tabular}{|l|c|c|c|c|c|}
\hline Treatments & Texture & Aroma & Color & Taste & $\begin{array}{c}\text { Overall } \\
\text { Acceptance }\end{array}$ \\
\hline Control & $3.55 \pm 0.96$ & $3.40 \pm 0.82$ & $4.45 \pm 0.96$ & $3.45 \pm 0.96$ & $3.55 \pm 0.96$ \\
\hline T1 & $3.75 \pm 0.50$ & $3.75 \pm 0.96$ & $4.10 \pm 0.58$ & $3.70 \pm 0.56$ & $3.88 \pm 0.82$ \\
\hline T2 & $4.25 \pm 0.50$ & $4.30 \pm 0.58$ & $3.90 \pm 0.56$ & $4.15 \pm 0.96$ & $4.20 \pm 0.82$ \\
\hline T3 & $4.55 \pm 0.96$ & $4.45 \pm 0.96$ & $3.65 \pm 0.50$ & $4.55 \pm 0.96$ & $4.50 \pm 0.58$ \\
\hline
\end{tabular}

\subsubsection{Texture}

The highest score for the texture evaluation by the panelists was obtained with reducedfat mayonnaise with $6 \%$ pumpkin flour added. The crude fiber content in pumpkin flour is $5.8 \%$. The addition of starch-containing materials can affect the resulting texture [12]. Reduced-fat mayonnaise with the addition of pumpkin flour has a very soft and very thick texture. The viscosity formed in mayonnaise is due to the presence of starch and pectin in pumpkin flour which functions as a stabilizer [10]. The addition of pumpkin flour with a higher percentage causes the mayonnaise to be more stable and thick. The addition of $6 \%$ pumpkin flour had a thick texture that was almost the same as full-fat mayonnaise. This addition can stabilize and replace the reduced oil composition of reduced-fat mayonnaise. 


\subsubsection{Aroma}

Highest score of aroma given by the panelists was in the treatment of $6 \%$ addition of pumpkin flour. T3 treatment of reduced-fat mayonnaise has a distinctive aroma of pumpkin. Pumpkin flour has a distinctive caramel and fragrant aroma that is different from other flours [13]. The more addition of pumpkin flour concentration causes the sour aroma of the mayonnaise decrease. The aroma of mayonnaise is caused by the use of ingredients such as oil, vinegar, eggs, and mustard [14]. Panelists like mayonnaise which has a less acidic aroma, thus giving the highest score in treatment 3 compared to the control treatment.

\subsubsection{Color}

Participants gave the mayonnaise the highest color rating without the addition of pumpkin flour. The higher pumpkin flour added concentration causes the color of the mayonnaise to be more yellow to brownish-yellow. This is because pumpkin flour has a yellow-orange color [15].

\subsubsection{Taste}

The control treatment had a sour taste, while the addition of $6 \%$ pumpkin flour had a sweet and sour taste produced by pumpkin flour. Pumpkin flour has a sweet taste [15]. The flavor-forming factors in mayonnaise are salt, sugar, and mustard and other optional ingredients are added to add flavor, color, and maintain the stability of the mayonnaise [16]. Mayonnaise is a portion of food that sour taste.

\subsubsection{Overall acceptance}

The overall acceptance score of the product is based on the texture, aroma, color, and taste formed. The addition of pumpkin flour to $6 \%$ reduced-fat mayonnaise was favored by the panelists. The resulting mayonnaise has a very soft and thick texture, a fragrant aroma typical of pumpkin, a brownish yellow color that can still be accepted by panelists, and a sour and sweet taste of mayonnaise and pumpkin flour.

\section{Conclusion}

Adding 6\% pumpkin flour to mayonnaise improves the quality of reduced-fat mayonnaise and is accepted by panelists.

\section{References}

[1] M. P. Gaikwad, H. M. Syed, D. D. Shinde, Journal of Pharmacognosy and Phytochemistry, 6, 06-09 (2017)

[2] C. Marchelina, H. Sinaga, L. M. Lubis, Indonesia Journal of Agricultural Research, 3, 10-22 (2020)

[3] M. Z. Amin, T. Islam, M. R. Uddin, M. J. Uddin, M. M. Rahman, M. A. Satter, Heliyon, 5, 1-5 (2019)

[4] W. Ashraf, A. Shehzad, H. R. Sharif, R. M. Aadil, M. R. Khan, L. Zhang, Journal of Food Processing and Preservation, 44, 1-11 (2020) 
[5] A. A. Torkova, K. V. Lisitskaya, I. S. Filimonov, O. A. Glazunova, G. S. Kachalova, V. N. Golubev, T. V. Fedorova,PloS one,13 (2018)

[6] S. El-Khatib, M. Muhieddine, The Health Benefit of Foods-current Knowledge and Further Development (Intechopen, London, UK, 2020).

[7] T. P. Keerthirathne, K. Ross, H. Fallowfield, H. Whiley, Pathogens, 5(4), 1-11 (2016)

[8] M. H. H. Amin, A. E. Elbeltagy, M. Mustafa, A. H. Khalil, Journal Agroaliment Proc Technology,20(1), 54-63 (2014)

[9] P. Ramachandran, A. K. Dhiman, S. Attri, Journal of Ecology, 44(6) 685-689 (2017)

[10] Y. Bai, M. Zhang, M, S. C. Atluri, J. Chen, R. G. Gilbert, Food Hydrocolloids, 106, 105894 (2020)

[11] S. Sharma, T. R. Rao, International Food Research Journal, 20(5), 2309 (2013)

[12] Đ. Ačkar, A. Jozinović, J. Babić, B. Miličević, J. P. Balentić, D. Šubarić, Innovative food science \& emerging technologies, 47, 517-524 (2018)

[13] Y. B. Pramono, D. Handayani, S. Mulyani, C. H. Wibowo, IOP Conference Series: Earth and Environmental Science, 803, 012039 (2021)

[14] D. Rahmawati, N. Andarwulan, H. N. Lioe, Jurnal Mutu Pangan: Indonesian Journal of Food Quality, 2, 80-86 (2015)

[15] S. H. Ghaboos, S. M. Ardabili, M. Kashaninejad, International Food Research Journal, 25 (2018)

[16] L. Golchoobi, M. Alimi, S. Shokoohi, H. Yousefi. Journal Texture Studies. 47, 1-10 (2016)

[17] H. Evanuarini, A. Susilo, IOP Conference Series: Earth and Environmental Science, 478, 1-6 (2020)

[18] H. Evanuarini, D. Amertaningtyas, D. T. Utama. IOP Conference Series: Earth and Environmental Science, 788, 1-8 (2021) 